\title{
Pengaruh konflik peran ganda (work family conflict) terhadap keberhasilan usaha (studi kasus pada Ikatan Pengusaha Muslimah Indonesia di Kota Jambi)
}

\author{
Kiki Widyasari*; Dahmiri; Sigit Indrawijaya \\ Program Studi Manajemen Fakultas Ekonomi dan Bisnis Universitas Jambi \\ *E-mail korepondensi: kikiwidyasari@yahoo.com
}

\begin{abstract}
This study aims to analyze the effect of multiple role conflict on the success of the business in the Jambi City IPEMI. This research was held at the IPEMI Gallery located on the Kambang River in Jambi City. The population in this study were Muslim women entrepreneurs who were members of the Jambi City IPEMI as many as 613 people. The sample in this study were 86 respondents using the probability sampling method, namely simple random sampling. The dependent variable in this study is multiple role conflict and independent variable namely business success. The results of this study show that partially influencing multiple role conflict has a positive and significant effect on business success.
\end{abstract}

Keywords: multiple role conflict, business success, IPEMI

\begin{abstract}
Abstrak
Penelitian ini bertujuan untuk menganalisis pengaruh konflik peran ganda terhadap keberhasilan usaha pada IPEMI Kota Jambi. Penelitian ini diadakan di Galery IPEMI yang terletak di Sungai Kambang Kota Jambi. Populasi dalam penelitian ini adalah pengusaha muslimah yang tergabung dalam IPEMI Kota Jambi sebanyak 613 orang. Sampel dalam penelitian ini sebanyak 86 orang responden dengan menggunakan metode probability sampling yaitu simple random sampling. Variabel terikat pada penelitian ini adalah konflik peran ganda dan variabel bebas yaitu keberhasilan usaha. Hasil dari penelitian ini menunjukan bahwa secara parsial konflik peran ganda berpengaruh berpengaruh positif dan signifikan terhadap keberhasilan usaha.
\end{abstract}

Kata kunci: konflik peran ganda, keberhasilan usaha, IPEMI

\section{PENDAHULUAN}

Paradigma lama yang mengungkapkan bahwa dunia bisnis selalu didominasi lakilaki terus memudar. Dalam beberapa tahun terakhir, pembentukan dan perkembangan bisnis baru yang dimiliki dan dijalankan perempuan meningkat signifikan di negara maju, diikuti negara-negara berkembang. Perempuan wirausaha di sini adalah mereka yang telah memulai bisnis dan terlibat secara aktif dalam mengelola bisnisnya. Di Indonesia, perkembangan perempuan wirausaha berkembang pesat. Keterlibatan kaum perempuan di dunia usaha, khususnya usaha kecil-menengah, cukup signifikan.

Berdasarkan data yang penulis dapatkan dari Dinas Tenaga Kerja, Koperasi, dan UKM Kota Jambi dapat dilihat bahwa jumlah wirausaha wanita hampir mencapai $50 \%$ dari jumlah wirausaha laki-laki yang tersebar di beberapa Kecamatan di Kota Jambi.

Dari Tabel 1 dapat diketahui bahwa wanita di zaman modern saat ini mulai mendominasi dalam berwirausaha, banyak alasan dibalik keinginan berwirausaha dan salah satunya adalah kesadaran wanita untuk membantu meningkatkan perekonomian keluarganya. Selain itu dengan adanya wanita berwirausaha dapat membantu mengurangi 
angka pengangguran yang ada di indonesia serta membuka lapangan kerja dan terciptanya peningkatan perekonomian negara melalui wirausaha.

Dengan adanya peran ganda yang diemban para wanita maka tidak dipungkiri akan adanya konflik dalam menjalani peran ganda tersebut atau work - family conflict yang berhubungan sangat kuat dengan depresi dan kecemasan yang diderita oleh wanita dibandingkan pria (Frone, dalam Triaryati, 2003).

Tabel 1.Jumlah Wirausaha Wanita dan laki-laki di Kota Jambi Tahun 2017

\begin{tabular}{clcc}
\hline No & Kecamatan & Jumlah wirausaha wanita & Jumlah wirausaha laki- \\
\hline 1 & Telanaipura & 415 & 458 \\
2 & Pelayangan & 249 & 178 \\
3 & Pasar & 321 & 336 \\
4 & Kota Baru & 390 & 486 \\
5 & Jelutung & 145 & 149 \\
6 & Jambi Timur & 504 & 570 \\
7 & Jambi Selatan & 314 & 367 \\
8 & Danau Teluk & 298 & 218 \\
9 & Alam Barajo & 481 & 356 \\
10 & Paal Merah & 297 & 480 \\
11 & Danau Sipin & 583 & 489 \\
\hline \multicolumn{2}{r}{ Total } & $\mathbf{3 9 8 8}$ & $\mathbf{4 0 8 7}$ \\
\hline
\end{tabular}

Sumber: Data diolah, 2020

Untuk di Kota Jambi sendiri sudah sangat banyak komunitas-komunitas yang mewadahi atau memfasilitasi pengusaha yang baru berkembang khususnya pengusaha wanita salah satunya adalah komunitas IPEMI (Ikatan Pengusaha Muslimah Indonesia). IPEMI adalah sebuah organisasi kemasyarakatan yang dibentuk dan didirikan untuk meningkatkan peran dan kontribusi Pengusaha Muslimah dalam pemberdayaan ekonomi masyarakat, menuju kemandirian ekonomi yang berkepribadian Indonesia dan berakhlakul karimah.

Dengan menjalankan 2 peran sekaligus ibu rumah tangga mampu menjalankan tanggung jawabnya namun disisi lain menjalankan peran ganda tersebut memiliki dampak tersendiri terhadap pekerjaan dan keluarga serta berdampak terhadap berhasil atau tidaknya usaha yang dijalankan tergantung bagaimana wanita wirausaha menyikapi dan mengambil keputusan terhadap setiap konflik yang terjadi selama wanita wirausaha menjalankan 2 perannya tersebut. Berdasarkan uraian diatas penulis tertarik untuk mengangkat penelitian yang berjudul "Pengaruh konflik peran ganda (work - family Conflict) terhadap keberhasilan usaha (studi kasus pada ikatan pengusaha Muslimah Indonesia di Kota Jambi)".

\section{TINJAUAN PUSTAKA}

\section{Konflik peran ganda (work-family conflict)}

Greenhouse dan Beutell (dalam Wirakristama dan Suharnomo, 2011) menyatakan bahwa konflik peran ganda adalah sebuah konflik yang timbul akibat tekanan-tekanan yang berasal dari pekerjaan dan keluarga. Sementara Menurut Menurut Greenhaus dan Beutell dalam Lambert et al., (2002) konflik pekerjaan- keluarga merupakan suatu bentuk konflik peran yang terjadi akibat ketidakseimbanga antara pekerjaan dan keluarga.

Ammons dan Beutell (dalam Hartini, 2009) menyatakan bahwa individu dengan pendidikan rendah cenderung mengalami konflik dari keluarga kemudian memengaruhi pekerjaan sedangkan individu yang memiliki pendidikan tinggi cenderung mengalami konflik dari pekerjaan yang memengaruhi keluarga karena hal ini terkait dengan strategi dalam mengatur tanggung jawab antara pekerjaan dan keluarga. 


\section{Keberhasilan usaha}

Menurut Moch. Kohar mudzakar dalam Ressa Andari (2011:21) keberhasilan usaha adalah sesuatu keaadan yang menggambarkan lebih dari pada yang lainya yang sederajat/ sekelasnya. Keberhasilan usaha merupakan utama dari sebuah perusahaan dimana segala aktivitas yang ada didalamnya ditujukan untuk mencapai suatu keberhasilan. Dalam pengertian umum, keberhasilan menunjukan suatu keadaan yang lebih baik atau unnggul dari pada masa sebelumnya.

Sehingga dapat diketahui bahwa keberhasilan usaha dapat dipengaruhi oleh kemampuan usaha yang tercermin diantarannya melalui pengetahuan, sikap, dan keterampilan dari pengusaha. Keberhasilan suatu usaha diidentikkan dengan laba atau penambahan material yang dihasilkan oleh pengusaha, tetapi pada dasarnya keberhasilan usaha tidak hanya dilihat dari hasil secara fisik tetapi keberhasilan usaha dirasakan oleh pengusaha dapat berupa panggilan pribadi atau kepuasaan batin.

\section{IPEMI (Ikatan Pengusaha Muslimah Indonesia)}

Ipemi terbentuk 21 April 2015 bertepatan dengan peringatan Hari Kartini, dengan terbentuknya dan kepengurusan IPEMI di seluruh Indonesia Ingrid Kansil mengharapkan peran pengusaha Muslimah dapat mendorong peningkatan perekonomian di Indonesia. Ikatan Pengusaha Muslimah Indonesia IPEMI di nahkodai Oleh Inggrid Kansil sebagai Ketua Umum, Aktivis Perempuan, artis presenter dan bintang sinetron sekaligus Politikus ini kini makin aktif terjun di organisasi Ikatan Pengusaha Muslimah Indonesia (IPEMI) yang sudah mencapai usia 1 tahun, IPEMI sebagai Organisasi Nasional kini pengurusnya sudah tersebar di 34 propinsi dengan jumlah anggota aktif sebanyak 5,1 juta di seluruh wilayah indonesia.

Inggrid Kansil juga mengimbau anggota Ipemi untuk meningkatkan kualitas produknya dalam rangka agar mempersiapkan diri bersaing pada Masyarakat Ekonomi ASEAN (MEA). IPEMI hadir mengawal pembangunan kewirausahaan muslimah, Sangat penting bagi kita mendampingi pelaku sektor usaha makro maupun mikro untuk menyiapkan daya saing secara Nasional. Sektor nasional juga harus siap untuk menghadapi persaingan yang semakin tinggi di lingkungan pasar domestik. MEA harus dapat menjadi peluang wirausaha muslimah Indonesia untuk memanfaatkan pasar ASEAN sekaligus sebagai penguatan wirausaha yang berbasis produksi dalam negeri ke kancah dunia internasional.

\section{METODE}

Objek penelitian ini adalah pengusaha muslimah yang tergabung dalam IPEMI Kota Jambi dengan mengambil sampel sebanyak 86 orang. Data yang digunakan diperoleh dari menyebarkan kuisioner secara online. Penelitian ini menggunakan analisis regresi linear sederhana.

Kegunaan analisis regresi linier sederhana menurut Jonathan Sarwono (2005:95) adalah: "Untuk mengukur besarnya pengaruh variabel bebas terhadap variabel tergantung dan memprediksi variabel tergantung dengan menggunakan variabel bebas".

Sumber : Sugiyono (2007)

$$
\mathbf{Y}=\mathbf{a}+\mathbf{b X e}
$$

Keterangan:

$\mathrm{Y}=$ Keberhasilan usaha

$\mathrm{X}=$ Konflik peran ganda (work family conflict)

$\mathrm{a}=$ Konstanta (nilai $\mathrm{Y}$ apabila $\mathrm{X}=0$ )

$\mathrm{b}=$ Koefisien regresi (nilai peningkatan ataupun penurunan)

$\mathrm{e}=$ Margin of error 
Analisis ini digunakan untuk mengetahui besarnya pengaruh konflik peran ganda terhadap keberhasilan usaha pengusaha muslimah yang tergabung dalam IPEMI Kota Jambi.

\section{HASIL DAN PEMBAHASAN}

Uji validitas adalah pengukuran yang menunjukkan tingkat ketepatan (kesahihan) ukuran suatu instrument terhadap konsep yang diteliti (Suharso, 2009:108). Deskripsi variabel konflik peran ganda terhadap keberhasilan usaha pengusaha muslimah Kota Jambi ditunjukkan oleh indikator atau pernyataan yang telah diajukan. Nilai $r_{\text {hitung }}$ diambil dari output SPSS Cronbach Alpha. Sedangkan nilai $r$ tabel diambil dengan menggunakan rumus $\mathrm{df}=\mathrm{n}-2$ yaitu $\mathrm{df}=86-2=84$, sehingga menghasilkan $r_{\text {tabei }}$ sebesar 0,1786 . Hasil uji validitas menunjukkan seluruh indikator dalam penelitian ini dinyatakan valid dengan memenuhi syarat adalah jika $r_{\text {hitung }}>r_{\text {tabei }}$ (Sugiyono: 2012). Untuk hasil lengkap dari uji validitas dapat dilihat pada Tabel 2 berikut:

Tabel 2 Hasil uji validitasi

\begin{tabular}{lccc} 
& Total item Correlation & R Tabel & Keterangan \\
\hline Pernyataan 1 & 0,226 & 0,1786 & Valid \\
Pernyataan 2 & 0,366 & 0,1786 & Valid \\
Pernyataan 3 & 0,341 & 0,1786 & Valid \\
Pernyataan 4 & 0,408 & 0,1786 & Valid \\
Pernyataan 5 & 0,563 & 0,1786 & Valid \\
Pernyataan 6 & 0,179 & 0,1786 & Valid \\
Pernyataan 7 & 0,183 & 0,1786 & Valid \\
Pernyataan 8 & 0,557 & 0,1786 & Valid \\
Pernyataan 9 & 0,191 & 0,1786 & Valid \\
Pernyataan 10 & 0,488 & 0,1786 & Valid \\
Pernyataan 11 & 0,474 & 0,1786 & Valid \\
Pernyataan 12 & 0,437 & 0,1786 & Valid \\
Pernyataan 13 & 0,427 & 0,1786 & Valid \\
\hline
\end{tabular}

Sumber: Data diolah, 2020

Berdasarkan Tabel 2 dapat diketahui bahwa nilai output SPSS Cronbach Alpha dari setiap butir pernyataan yang diberikan kepada responden lebih besar dari nilai $r_{\text {tabe }}=$ 0,1786, yang berarti semua butir pernyataan dinyatakan valid. Hasil penelitian ini menunjukkan bahwa konflik peran ganda berpengaruh positif dan signikan terhadap keberhasilan usaha. Dimana hal ini dapat diketahui dari hasil penelitian diatas bahwa konflik peran ganda memiliki pengaruh yang signifikan dan positif secara parsial yaitu sebesar 34,3\% terhadap keberhasilan usaha pengusaha muslimah yang tergabung di dalam IPEMI Kota Jambi. Sesuai dengan hasil penelitian Ida Ayu Widyanigrum (2012) yang berjudul Pengaruh Konflik Peran Ganda Dan Stres Kerja Terhadap Kinerja Karyawan Wanita Pada Swalayan Era Mart 5000 Di Samarinda yang menyimpulkan bahwa variabel konflik pekerjaan - keluarga (X1) dan variabel stres kerja (X3) bernilai positif maka kedua variabel tersebut secara bersama - sama berpengaruh positif terhadap kinerja karyawan.

Hasil temuan penelitian menunjukkan adanya hubungan satu sama lain antara variabel independen dan variabel dependen. Hal ini diperoleh melalui jawaban responden pengusaha muslimah yang berjumlah 86 orang. Dengan skala usaha 10 - 20 Tahun sebanyak 2,3\%, 20 - 30 Tahun sebanyak 27,9\%, 30 - 40 Tahun sebanyak 39,5\%, dan > 40 Tahun sebanyak $30 \%$.

Untuk hubungan antara konflik peran ganda dan keberhasilan usaha diperoleh nilai $\mathrm{R}=0,107$ sedangkan dari hasil perhitungan uji $\mathrm{t}$ untuk yang menghasilkan $\mathrm{t}$ hitung $=$ 
3,342, sedangkan nilai t tabel $=1,663$ dengan nilai signifikan yang lebih kecil dari nilai probabilitas $(0,001<0,05)$, yang artinya terdapat hubungan positif dan signifikan konflik peran ganda terhadap keberhasilan usaha. $\mathrm{H} 1$ diterima dan $\mathrm{H} 0$ ditolak.

Hasil penelitian ini menunjukkan bahwa konflik peran ganda berpengaruh positif dan signikan terhadap keberhasilan usaha. Dimana hal ini dapat diketahui dari hasil penelitian diatas bahwa konflik peran ganda memiliki pengaruh yang signifikan dan positif secara parsial yaitu sebesar 34,3\% terhadap keberhasilan usaha pengusaha muslimah yang tergabung di dalam IPEMI Kota Jambi. Sesuai dengan hasil penelitian Ida Ayu Widyanigrum (2012) yang berjudul Pengaruh Konflik Peran Ganda Dan Stres Kerja Terhadap Kinerja Karyawan Wanita Pada Swalayan Era Mart 5000 Di Samarinda yang menyimpulkan bahwa variabel konflik pekerjaan - keluarga (X1) dan variabel stres kerja (X3) bernilai positif maka kedua variabel tersebut secara bersama - sama berpengaruh positif terhadap kinerja karyawan. Hasil temuan penelitian menunjukkan adanya hubungan satu sama lain antara variabel independen dan variabel dependen. Hal ini diperoleh melalui jawaban responden pengusaha muslimah yang berjumlah 86 orang. Dengan skala usaha 10 - 20 Tahun sebanyak 2,3\%, 20 - 30 Tahun sebanyak 27,9\%, 30 40 Tahun sebanyak 39,5\%, dan > 40 Tahun sebanyak 30\%. Untuk hubungan antara konflik peran ganda dan keberhasilan usaha diperoleh nilai $\mathrm{R}=0,107$ sedangkan dari hasil perhitungan uji $\mathrm{t}$ untuk yang menghasilkan $\mathrm{t}$ hitung $=3,342$, sedangkan nilai t tabel $=1,663$ dengan nilai signifikan yang lebih kecil dari nilai probabilitas $(0,001<0,05)$, yang artinya terdapat hubungan positif dan signifikan konflik peran ganda terhadap keberhasilan usaha. $\mathrm{H} 1$ diterima dan $\mathrm{H} 0$ ditolak.

\section{KESIMPULAN DAN SARAN}

\section{Kesimpulan}

Berdasarkan hasil penelitian dan pembahasan yang telah dilakukan mengenai pengaruh variabel konflik peran ganda terhadap keberhasilan usaha pengusaha muslimah yang tergabung dalam IPEMI Kota Jambi, maka dapat disimpulkan bahwa penelitian ini mendukung hipotesis yang diajukan yaitu: Konflik peran ganda berpengaruh positif dan signifikan terhadap keberhasilan usaha pengusaha muslimah yang tergabung dalam IPEMI Kota Jambi maka dapat disimpulkan bahwa variabel konflik peran ganda mempunyai pengaruh bersama-sama yang signifikan dengan variabel dependen keberhasilan usaha yang dimiliki pengusaha muslimah sudah menikah. Hal ini dapat dimengerti mengingat pengusaha muslimah lebih memiliki manajemen diri sendiri, yang dapat menguntungkan bagi dirinya sendiri yang menanggung peran ganda, baik dalam rumah tangga keluarga, maupun dalam urusan usaha.

\section{Saran}

Pengusaha muslimah yang btergabung dalam IPEMI Kota Jambi yang sudah menikah sebaiknya lebih mengefektifkan manajemen diri terutama waktu dalam penyelesaian tugas yang menyangkut usaha sehingga dapat melaksanakan tugasnya sebagai ibu rumah tangga tanpa memikirkan pekerjaan ketika sudah pulang dari tempat usahanya dan lebih mengontrol diri dalam menghadapi permasalahan baik di tempat usaha maupun dalam rumah tangganya sehingga dapat menyelesaikan permasalahan tersebut dengan tepat.

\section{DAFTAR PUSTAKA}

Arifin, Riva. (2016). Fungsi dan peranan wirausaha. sumber: (https://rivaarifin.blogspot.co.id/2016/04/fungsi-dan-perananwirausaha.html).Date: 2016-04-12. Dikunjungi 10 November 2018. 
Anonim. (2017). Ratio Wirausaha Indonesia Naik Jadi 3,1 Persen. Sumber:(http://www.depkop.go.id/content/read/ratiowirausahaindonesia-naikjadi-31-persen). Date: 2017-03-11. Dikunjungi 09 November 2018.

Dalimunthe, Amazon. (2018). Inggrid kansil resmikan kantor baru ikatan pengusaha muslimah (IPEMI). Date: 2018-03-02. Dikunjungi 21 November 2018.

Dinda, Annisa D. (2018). Pengaruh konflik peran ganda dan self-efficacy terhadap kinerja karyawan wanita pada PT Nusantara Tropical Farm Lampung Timur. Fakultas Ekonomi dan Bisnis. Universitas Lampung.

Fank, Hermann, et all. (2011). Conflicts in family firms: state of the art andperspectives for future research. WU Vienna University of Economics and Business. Vienna, Austria.

Hendrayati, Heny. (2017). Menggerakkan Perempuan Wirausaha Jabar. Sumber:(http://www.pikiranrakyat.com/opini/2017/08/18/menggerakkanperempuan-wirausaha-jabar-407655). Date: 2017-08-18. Dikunjungi 01 November 2018.

Hendro. (2011). Dasar-dasar kewirausahaan. Erlangga : Jakarta.

Indriani, Azazah. (2009). Pengaruh konflik peran ganda dan stress kerja terhadap kinerja perawat wanita rumah sakit (studi pada Rumah Sakit Roemani Muhammadiyah Semarang. Universitas Diponegoro.

Jose, Eugenio Y. (2014). Family business conflicts. Universitat Jaume.

Komunita.id. 2018. Ikatan Pengusaha Muslimah Indonesia. Sumber : (https://komunita.id/listing/ikatan-pengusaha-muslimah-indonesia/). Date: 201805-14. Dikunjungi 05 November 2018.

Meidah, Endah. (2013). Pengaruh konflik peran ganda, kecerdasan emosional dan komitmen organisasi terhadap kinerja perawat wanita (studi kasus pada Rumah Sakit Islam Jakarta Pondok Kopi). Fakultas Ekonomi dan Bisnis. Universitas Islam Negeri Syarif Hidayatullah.

Roboth, Jane. Y. (2015). Analisis work family conflict, stres kerja dan kinerja wanita berperan ganda pada yayasan compassion East Indonesia . Program Magister Manajemen. Fakutas Ekonomi Dan Bisnis. Universitas Sam Ratulangi.

Susanto. (2009). Analisis pengaruh konflik kerja-keluarga terhadap kepuasan kerja pengusaha wanita di Kota Semarang.Magister Manajemen. Universitas Diponegoro.

Suryana, Yuyus, dkk. (2010). Kewirausahaan pendekatan karakteristik wirausahawan sukses. Kharisma Putra Utama : Jakarta.

Suryana. (2013). Kewirausahaan kiat dan proses menuju sukses. Salemba: Jakarta.

Sujarweni, Wiratna V. (2015). metodologi penelitian bisnis \&ekonomi. Pustakabarupress : Yogyakarta.

Wirakristama, Ricardus C. (2011). Analisis pengaruh konflik peran ganda (work family conflict) terhadap kinerja karyawan wanita pada Pt Nyonya Meneer Semarang Dengan Stres Kerja Sebagai Variabel Intervening. Skripsi, Fakultas Ekonomi. Universitas Diponegoro. 